\title{
Study on the Shunt Teaching Mode of College English in Colleges and Universities
}

\section{Bing Bai}

Xi'an Aeronautical University, Xi'an City 710077, Shaanxi Province, China

\begin{abstract}
There are different teachers in China, which leads to great differences in the English ability of new college students. Therefore, the implementation of English teaching mode in colleges and universities has been widely recognized and accepted in China. Through the shunt teaching, colleges and universities in China will be more suitable for the learning rules and development needs of English, which is the necessary guarantee for individualized teaching. In practice, there are also many problems in English diversion teaching, which requires us to guide the freshmen to arrange their learning psychology. Through teaching diversion, colleges and universities can start students' emotional motivation, which will be more conducive to CET-4. Through the teaching diversion, this paper analyzes how to guarantee the training mode of the students who have not passed the CET-4. Then, this paper puts forward some suggestions, which can better stimulate students' interest in learning.
\end{abstract}

Keywords: College English; Shunt Teaching Mode; CET-4

\section{Introduction}

In recent years, shunt teaching conforms to the basic principle of individualized English teaching, which has been recognized by more and more universities. The split teaching mode is in line with the cognitive law of language learning, which will better reflect the respect for individual differences of students. By fully respecting the basic level of students, targeted teaching can be carried out, which will promote the enthusiasm of students in language learning. Because each student's English basic level is different, and the student's English level is quite different, which needs to carry on the English shunt teaching. At present, the main purpose of college English teaching is to carry out CET-4. In this paper, CET-4 is the main dividing line for the diversion. First, this paper focuses on how to stimulate students' interest in English learning. Second, this paper aims at what kind of training methods have been adopted by the students who have passed CET-4. Through the teaching diversion, teachers can better make courseware, which can better carry out appropriate courses.

\section{College English teaching standards}

Whether this paper has passed CET-4 or not is the standard to be divided. Therefore, after the students take the first CET-4, they can be divided into two levels. Among them, the first level is those who passed CET-4, and the second level is those who failed CET-4. Through the rearrangement of classes, English courses with different contents for students of different levels should be carried out, which has many advantages. First, to clarify the learning objectives of students: CET-4 is widely recognized by the society, which is an important basis for students to enter school and get

Copyright (C) 2020 Bing Bai

doi: $10.18282 /$ le.v9i3.828

This is an open-access article distributed under the terms of the Creative Commons Attribution Non-Commercial License

(http://creativecommons.org/licenses/by-nc/4.0/), which permits unrestricted non-commercial use, distribution, and reproduction in any medium, provided the original work is properly cited. 
employment. Through the clear grading standard, students can clear and practical learning objectives, which will improve the students' learning objectives and planning. Second, through English diversion, students' emotional factors can be improved, which will avoid negative impact on students. Through a good beginning, students will increase their confidence and enthusiasm in English learning. Third, the students' English level should be measured effectively. CET-4 has high reliability and validity, which is a test for non-English majors. CET-4 is a social recognition and it will have a more objective measurement standard. Therefore, by taking CET-4 as the standard, colleges and universities can get rid of the manpower and material resources of organizing the grading examination independently, which is also more credible.

\section{Problems existing in shunt teaching}

This paper is based on the field survey. 500 formal questionnaires and 491 effective questionnaires were sent out, and the effective rate was $98.2 \%$.

\subsection{Negative learning attitude}

After English teaching, the second level students are mostly in a negative state. Therefore, some students' learning attitude is not correct, which causes them not to concentrate on class and participate in classroom activities. According to the survey results, the main problem is negative attitude towards English learning, accounting for $65.9 \%$. The second is lacking of learning motivation, accounting for $60.0 \%$. Details are shown in Figure 1.

Negative attitude towards English learning Insufficient understanding of the importance of English

Lack of learning motivation

Not paying attention to class

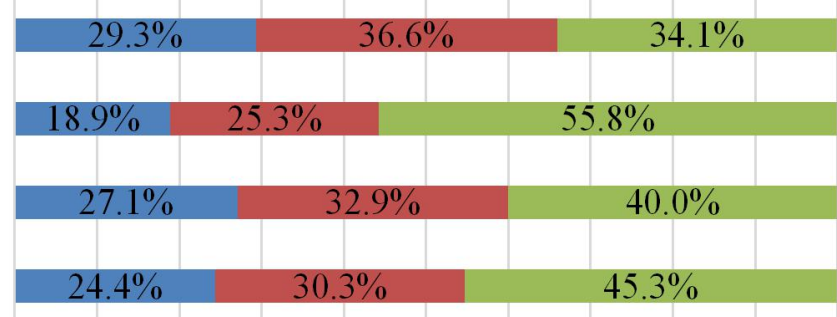

$0 \% \quad 10 \% \quad 20 \% \quad 30 \% \quad 40 \% \quad 50 \% \quad 60 \% \quad 70 \% \quad 80 \% \quad 90 \% 100 \%$

Very agree $\square$ Agree $\square$ Disagree

Figure 1. Negative learning attitude.

\subsection{Psychological imbalance}

After English teaching, the second level students will have psychological imbalance, which can cause extreme psychology. In this paper, the students think that it is a shame to fail CET-4, which will lead to a kind of self-abandonment. According to the survey results, the main problem is strong inferiority, accounting for $67.9 \%$. The second is the psychology of self-abandonment, accounting for 57.9\%. Details are shown in Figure 2. 
The psychology of self abandonment

Low interest in learning

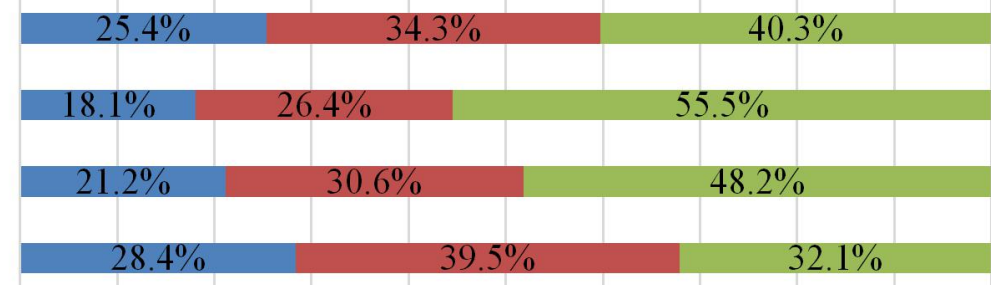

Strong inferiority

$\begin{array}{lllllllllll}0 \% & 10 \% & 20 \% & 30 \% & 40 \% & 50 \% & 60 \% & 70 \% & 80 \% & 90 \% & 100 \%\end{array}$

Very agree $\square$ Agree $\square$ Disagree

Figure 2. Psychological imbalance.

\subsection{Lack of good habits}

After English teaching, part of the second level students lack good learning habits and correct learning methods, which will reduce their learning effect. Some students do not pay attention to listening and speaking training, which will reduce their learning ability. According to the survey results, the main problem is lacking of correct learning methods, accounting for $74.1 \%$. The second is low implementation rate of learning plan, accounting for $64.6 \%$. Details are shown in Figure 3.

Low implementation rate of learning plan

Lack of scientific study plan
Lack of correct learning methods
Lack of good study habits

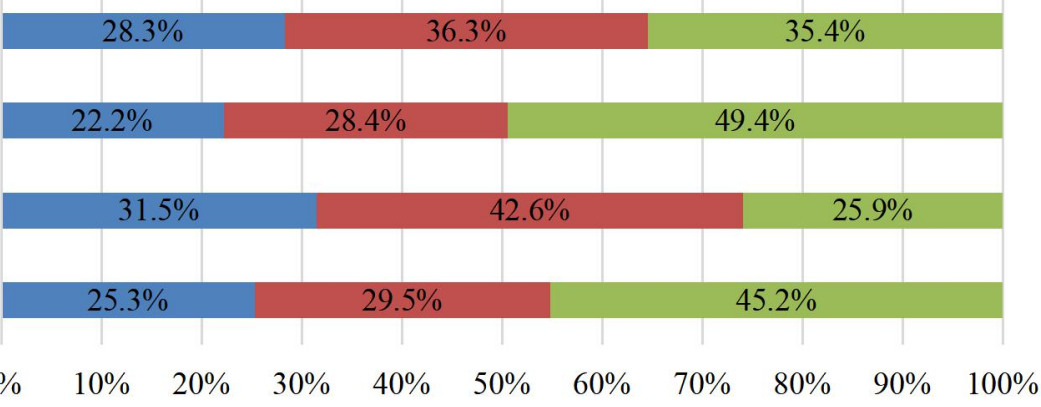

$\square$ Very agree $\square$ Agree $\square$ Disagree

Figure 3. Lack of good habits.

\section{The implementation of college English diversion teaching}

For two levels of students, teachers should make different English learning needs, which needs to adjust the teaching objectives, contents and methods of college English.

\subsection{Teachers should make teaching objectives and plans in different categories}

For the first level students, English teaching should improve the comprehensive skills of listening, speaking, reading and writing, especially the ability of language use and self-study, which will lay the foundation for English application. For the second level students, teachers should consolidate the basic knowledge and skills, which need to focus on cultivating their vocabulary memory, grammar, sentence patterns, etc. Through the intensive training, teachers can teach the methods and skills of problem-solving, which can improve the pass rate of CET-4.

\subsection{Set up the teaching content by category}

For the first level students, teachers should improve their listening and speaking ability, which will improve their enthusiasm and interest. Through English audio materials, students can improve their interest. Therefore, teachers should organize students to watch the original films, advertisements, audio and video content, etc. At the same time, 
teachers can set up film dubbing, film production and so on, which can improve the fun of students learning English. For the second level students, their listening, speaking, reading, writing and other aspects of the ability are lacking, which requires them to combine the textbook and the contents of the fourth level examination, which will better meet the requirements of students. By focusing on developing students' reading and listening abilities, teachers can help them successfully pass the CET-4.

\subsection{Adopt different teaching methods}

The first level students have a large vocabulary, reading ability and listening ability. Therefore, teachers should pay attention to improving their oral and writing abilities. By teaching in English, teachers can improve their autonomous learning ability. Through a variety of teaching methods, such as situational teaching, task-based teaching and project-based teaching, teachers can fully mobilize students' learning autonomy and creativity. For the second level students, teachers can adopt heuristic teaching and task-based teaching, which will improve their grammar rules, vocabulary structure, etc. Bilingual teaching can strengthen students' training, which will enhance students' confidence in learning.

\section{Conclusion}

Shunt teaching is the inevitable result of the deepening of college English teaching reform, which is the necessary guarantee to improve the quality of college English teaching. English diversion can meet the principle of individualized teaching, which is an English teaching method to improve the overall efficiency. However, English diversion teaching is not a universal teaching method, which requires colleges and universities to solve problems in teaching. Through further research and practice, the English diversion teaching will continue to improve and perfect. Through different course contents, teaching modes and plans, colleges and universities can meet the needs of different students. Therefore, the inferiority of low-level students must be alleviated, which will be better for shunt teaching.

\section{References}

1. Miao Y. Thinking about the orientation of independent colleges in the transformation and development (in Chinese). China Higher Education 2011; (7): 52-53.

2. Liu Q. The growth fit purpose of college students in the division teaching of Normal University (in Chinese). Academic Exploration 2013; (8): 155-158.

3. Ren R. Building a new college English teaching model suitable for independent colleges (in Chinese). Journal of Zhejiang Wanli University 2007; (1): 172-174.

4. Wang D. Probe into the theoretical basis of the multi-level teaching of college English. Journal of Anhui University of Technology 2010; (3): 114-115.

5. Li J, Du M. Discussion on class division in college English stratified teaching (in Chinese). Examination Weekly 2010; (17): 115-116.

6. Zhang M. Research on slow class teaching in all-round development college English stratified teaching (in Chinese). Science and technology information 2011; (9): 142-145. 